Edith Cowan University and Queensland University of Technology

\author{
Ffion Murphy and Philip Neilsen
}

\title{
Recuperating writers - and writing: the potential of writing therapy
}

\begin{abstract}
Writing therapy usefully creates, or makes explicit, common ground between literature and medicine, arts and sciences, and between clinical and community sectors and the academy. It draws upon multiple theories of language, memory, pain, subjectivity, identity, creativity, and the unconscious and is a site at which the concerns of established and emerging disciplines and interest groups coalesce; for example, literary studies, psychoanalysis, narrative therapy, narrative medicine, trauma studies, human rights, life-writing, and testimony studies. This article maps the field to indicate the breadth and potential of writing therapy as well as its risks and difficulties, and also suggests ways in which the practice and theory of therapeutic writing relates to and might be compatible with the practice and theory of creative and life-writing. Research suggests that writing may be most beneficial to health if it moves through developmental stages typical of writing designed for a readership. Transformation in the writing over time is relevant to both literary and health assessments. The article concludes that writing therapy presents a fascinating challenge for the discipline of creative writing and that there is potential for university writer-teachers to investigate writing therapy in academic, health science and community settings.
\end{abstract}

Writing therapy usefully creates, or makes explicit, common ground between literature and medicine, arts and sciences, and between clinical and community sectors and the academy. In this article, we discuss the origins and development of writing therapy and consider some of the ways in which the practice and theory of therapeutic writing relates to the practice and theory of creative and professional writing. The territory is mapped to suggest its breadth and potential as well as its difficulties: in our view, university writer-teachers might usefully investigate and deploy writing therapy in both academic and community settings.[1]

Peggy Munson, who was struck down by Chronic Fatigue Immune Dysfunction Syndrome when she was 23, claims that writing 'splints the wounded body, gives it a much-needed papyrus cradle in which to rest, allowing it to reconstruct itself, to graft new stories onto its troubled surface, and to heal' (2000: 24). In an interview, poet, novelist, and playwright Dorothy Hewett claimed that turning painful autobiographical material into fiction was 'therapeutic and helpful'. She added, 'Some people go to psychiatrists ... but I use writing. I think a lot of playwrights use their craft to try and make a pattern out of life. I think this is one of the driving forces behind writing, because life is so unpatterned' (in Baker 1986: 198). 
In The writing cure: how expressive writing promotes health and well-being, Stephen Lepore and Joshua Smyth observe that 'in addition to drawing on traumatic life experiences as a source of inspiration, poets and novelists for centuries have viewed writing as a way of transforming trauma and healing themselves and others' (2002: 6). It was not until the early twentieth century, however, that the term bibliotherapy was coined to describe the intentional use of literature - of reading - for therapeutic purposes (Rubin 1978a: xi). As the century progressed an 'ethics of voice, affording each a right to speak her own truth, in her own words' (Frank 1995: xii) emerged in the context of postmodernism and the term's ambit expanded to include expressive and creative writing by published authors, poets, and journalists, as well as by those who would not describe themselves as writers, with a view to self-reflection and healing. A new term, 'writing therapy', also came into popular and clinical use.

Arthur Frank observes in The wounded storyteller that 'self-stories' have become a recognisable form of popular culture: that is, illness stories, spiritual autobiographies, stories of sexuality and gender identity, and 'survivor stories of inflicted traumas such as war, captivity, incest, and abuse' (1995: 69). A market exists for stories of 'narrative wreckage' that are also, usually, stories of reconciliation, resistance, recovery, or restoration, and these stories, in turn, influence how further stories are told - the published and marketable versions are part of a much broader discourse. This creates an interesting paradox: 'in an age of narrative wreckage, an enhanced belief in the efficacy of stories emerges' (1995: 196).[2]

In 1999, Debbie Taylor, novelist and editor of Mslexia: the magazine for women who write (produced in the UK), published a feature article entitled 'Writing as Therapy' which begins: 'Authors are eight times more likely than the general population to be clinically depressed. Yet a growing band of writing therapists say writing is good for you. Does your writing keep you sane - or could it be driving you mad?' This is a reasonable question. It recalls another posed by Jen Webb in her disturbing article 'Depression and Creative Writing' (2003): Do writing students experience depression more than other students? Webb reflects:

Last semester a disturbingly large number of the first year writing students presented with documented depression, anxiety, obsessive-compulsive disorder, bipolar disorder, Asperger syndrome, schizophrenia ... On bad days, it seems as though almost every student in my program is riddled with sorrow, anxiety, and the incapacity to be at home in the world.

Taylor points to research studies by Nancy Andreasen (1987), Felix Post (1994; 1996) and Arnold Ludwig (1994), which indicate that writers suffer from depression and other forms of mental disturbance at a significantly higher rate than the general population. Webb cites a study by Kay Redfield Jamison (1994) that concurs with Post's findings, and she also notes statistics that show rates of suicide and attempted suicide among writers to be between six and eighteen times higher than those of the general population.

These studies, which support popular views of the writer as childish, mad, or troubled - and of art as symptomatic (see Freud 1953-75) - perhaps indicate the ideological or discursive baggage that persists from highly coloured and Romantic constructions of the artist as tortured soul, and may well irritate those who prefer to emphasise literary technique, convention, intertextuality, experimentation, process, craft, and critical labour as the real sources of fiction and poetry. 
Post suggests the problem may lie with the process of writing which produces acute mental imagery and inner struggle, but Taylor considers that the writer's solitary, sedentary, and often financially and professionally unrewarding work may be at least partly to blame. Bemused, she observes: 'Becoming a writer ... can seriously damage your health'. Herein lies a paradox:

to suggest that emotionally unstable or physically vulnerable people should use writing as a form of therapy would seem tantamount to giving them razor-blades to play with. But that is exactly what has been happening in hospitals, day-centres, hospices, prisons - even GP surgeries - up and down the country in the last few years.

Taylor is clearly overstating the case and eliding differences between writing for publication and writing for therapy. Nevertheless, her comments, like Post's, remind us that caution is necessary when considering writing as therapy. There are other, more potent reminders, of course. Jeffrey Berman finds that the 'mocking irony' of Sylvia Plath's The Bell Jar is that 'even as it dramatizes Esther Greenwood's collapse and apparent recovery, autobiography intrudes to remind us of the failure of therapy and art to sustain Sylvia Plath's life' (1985: 121). Writing did not save Plath from suicide, as it has not saved various other writers, including Anne Sexton and Virginia Woolf - or perhaps it is the case that the power of writing to save anyone is limited.

In a 1992 article published in The Arts in Psychology, Lester and Terry claim that 'Anne Sexton illustrates the dialectic in poetry as therapy, between expression and catharsis on the one hand and cognitive control on the other ... As she perfected her poems, she was, perhaps, able to achieve an intellectual distancing from, and control over the emotions that initially stimulated the content of the poems.' They add:

It may be that only when writers are forced to craft their expressive products into formal works of art is there a psychotherapeutic effect. Several commentators ... believe that Sexton lived as long as she did because she was able to do this. Had she not been introduced to poetry by her therapist she might well have killed herself sooner. (cited Bolton 1999: 101) [3]

These views are speculative, of course, and may seem indefensible to those dubious about links between writing and healing. Morris Morrison observes (perhaps loftily) that for some, the development of creative arts for therapeutic purposes seems a 'denigration of the artistic process' (Morrison 1987: 22). Though disappointed by that notion, Morrison advises that writing can be 'countertherapeutic' when employed 'primarily in competition for recognition and fame, rather than self-definition' for 'failure may trigger a serious depression'. Furthermore, those predisposed to 'delusional thinking' should not be encouraged 'to wander afield in the world of fantasy' for this 'could prove treacherous'. He also suggests that a 'deeply disturbed' individual 'should not be encouraged to open the Pandora's box of his unconscious without a therapist' and adds, 'Dante enlisted Virgil as a psychotherapist when he ventured into the Inferno' (1987: 211-12).

There are further complications. Mary Stuart reminds that 'many individuals fear writing' and that many writers feel 'inadequate and angry when confronted with the constraints of writing', partly because of the 'connections between writing and the discourse of education'. Importantly, she concludes that ' $[\mathrm{t}] \mathrm{he}$ 
significance of writing to personal development is ... contradictory and powerful, and should be recognised and analysed carefully' (1998: 150-51).

A practice might proliferate even as the discourse that underpins and justifies it attempts to better establish its validity and extend its reach. In 'Poetry as research: advancing scholarship and the development of poetry therapy as a profession', Rich Furman points out that the 'legitimization of a profession is often a long and arduous task' and that '[v]arious stakeholders, at times with competing interests and world views, must find common ground while forming collegial and professional bonds' (2006: 133). The establishment of associations, training programs, and journals is necessary if professions are to accumulate and disseminate knowledge and receive legitimisation within their own domain and from society at large. Furman contends that for writing therapy to achieve greater credibility and acceptance 'it must further develop its own knowledge base and research methodologies' (2006: 134). This work is well underway and it is certainly the case that interest in writing as therapy has risen dramatically over the past two decades among psychologists, psychotherapists, general practitioners, patients, creative writers, teachers, community arts and health funding bodies, publishers, and the public.

Its emergence began several decades earlier, however, when psychotherapists and librarians began to experiment with bibliotherapy and to publish their views on literature's value as a tool for healing. For example, Robert Schauffler published The poetry cure: a pocket medicine chest of verse in 1925. By 1950, over 400 articles on bibliotherapy had been published (Rubin 1978a: 4). In 1960, psychiatrist Smiley Blanton published The healing power of poetry based on his use of poetry with patients. Like Schauffler, he 'maintained a prescriptive approach often using inspirational poetry' (Mazza 1993: 6). In 1963, pharmacist and lawyer Eli Greifer produced Principles of poetry therapy and his work influenced psychotherapist Jack Leedy who edited Poetry therapy: the use of poetry in the treatment of emotional disorders (1969). Molly Harrower, a psychologist, published The therapy of poetry in 1972 and the following year Leedy edited Poetry as healer: mending the troubled mind (1973) which built on earlier work demonstrating the use of poetry in practice. Twelve years later, in 1985, he edited another book along similar lines: Poetry the healer: Mending the troubled mind (Mazza 1993: 7). In 1978 clinical psychologist Arthur Lerner edited Poetry in the therapeutic experience and librarian Rhea Joyce Rubin published a bibliotherapy guide and also a sourcebook. Publishing in the field continued throughout the 1980s; poet and poetry therapist Ruth Lisa Schechter, who worked with rape victims and people with addiction in the 1970s, published Poetry therapy: a therapeutic tool and healing force in 1983 and Morris Morrison edited Poetry as therapy in 1987. An influential overview, Biblio/poetry therapy - The interactive process: A handbook by Arleen Hynes and Mary Hynes-Berry, was first published in 1986. Hynes and Hynes-Berry also published Biblio/poetry therapy: A resource bibliography in 1992 (National Association of Poetry Therapy 1999).

Publications throughout the 1990s and into the twenty-first century have continued to provide evidence of writing's therapeutic benefits and, in many cases, practical guidance for those interested in incorporating writing in clinical practice, health-care settings, community writing workshops, or educational institutions. For instance, Jessica Kingsley Publishers, an award-winning independent British publisher specialising in arts, health sciences and social care, has established over the past decade an impressive list of publications promoting creative arts therapies, including a series entitled 'Writing for Therapy and Personal Development', which includes The self on the page: theory and practice of creative writing in personal development (1998) edited by Celia Hunt and Fiona Sampson, The therapeutic potential of creative 
writing: writing myself (1999) by Gillie Bolton, Writing well: creative writing and mental health (1999) by Deborah Philips, Liz Linington and Debra Penman, Therapeutic dimensions of autobiography in creative writing (2000) by Celia Hunt, Writing my way through cancer (2003) by Myra Schneider, Creative writing in health and social care (2004) edited by Fiona Sampson, Can you read me? Creative writing with child and adult victims of abuse (2004) edited by Jacki Pritchard and Eric Sainsbury, and Writing works: A resource handbook for therapeutic writing workshops and activities (2006) edited by Gillie Bolton, Victoria Field and Kate Thompson.

This is just a fraction of books published in the field in the past decade (for example, see also Fox 1997; DeSalvo 1999; Mazza 1999; Zimmerman 2002; Pennebaker 2004). In addition, numerous journal articles across a range of disciplines present the results of quantitative and qualitative research demonstrating that writing is beneficial to both physiological and mental health, some of which are referred to below.

Journal writing is a notable subset of writing therapy, with its own tradition. Although a centuries-old practice it was formalised as a therapeutic technique by Jungian psychologist Ira Progoff, who founded Dialogue House in New York to run workshops based on his highly structured 'intensive journal method', which is described in At a journal workshop (Progoff 1975). Kathleen Adams, author of Journal to the self (1990) and Mightier than the sword (1994), established the Center for Journal Therapy in Colorado, and many centres and websites on this theme have since been set up in the US and elsewhere. Letter therapy, sometimes approached as part of journal therapy, tends to mimic public or interpersonal communication, generating candid communications addressed, but not usually sent, to significant others. A few years ago, Lori Stone, a researcher in the field of writing therapy, conducted an Internet search for references to journaling and found more than 9000 books on amazon.com; a standard search engine located 22,000 sites for journaling, many of which were personal entries (Pennebaker 2002: 290-91).

Although it has been contended that therapeutic writing is 'seriously underresearched, and under-reported, especially in British clinical practice' (Bolton and Wright 2004: 229), the use of literary arts in therapy is professionally organised and recognised in the United States and United Kingdom. In the US, for example, an Association for Poetry Therapy was established in 1969 and incorporated in 1981 as the National Association for Poetry Therapy (NAPT). NAPT's mission is 'Promoting growth and healing through language, symbol and story'. NAPT is a membership organisation but also has a credentialing arm, the National Federation for Biblio/Poetry Therapy.[4]

Twenty years ago, in 1987, NAPT began publishing the Journal of Poetry Therapy: The Interdisciplinary Journal of Practice, Theory, Research, and Education. Contributors and members of NAPT have a common interest in the role of 'language arts in therapeutic, educational and community building capacities'. Nicholas Mazza, editor since the journal's inception, lists:

[n] arrative therapy, bibliotherapy, journal writing, metaphor, storytelling, song, theatre arts and, of course, poetry' as within the purview of poetry therapy, and explains that the field has 'a pluralistic base drawing from both the helping professions (e.g., social work, psychology, medicine, education, and counselling) and literary groups (e.g., writers/poets, literary critics, and English professors). (Mazza 2003) 
The journal includes articles on research, clinical practice, and theoretical and literary studies (NAPT 1999).

In the UK, an Association for the Literary Arts in Personal Development, or Lapidus, was founded by the English Arts Council in 1996. Like NAPT, it brings together a range of disciplinary interests and promotes the 'writing, reading and performing of poetry, prose, fiction, drama and story' for 'healing and personal growth' (Lapidus 2006):

Lapidus exists to establish resources for the exchange of information and ideas, to promote appropriate training and ethical research in the field, and to provide practical support for practitioners ... Members include nonprofessionals, writers and poets, medical and healthcare professionals, therapists, social workers, librarians, academics, teachers, service users, survivors and service providers who may work in a variety of therapeutic environments.

In Australia, art, music, and drama therapy are reasonably well-established fields of practice and research: professional organisations represent members and there exist journals and systems of training and accreditation (see, for example, ANZATA 2006; AMTA n.d.; ANZPA 1999). However, although writing appears to be widely used as an adjunctive therapy or personal development tool in private, clinical, and community settings, there is currently no Australian equivalent to NAPT or Lapidus. Poetry therapy has an international base according to Mazza: the Journal of Poetry Therapy has published contributions from 'Finland, Venezuela, Russia, Canada, South Africa and Israel' (2003: 1), but not, as far as we know, from Australia.

The link between arts and health has caught the imagination of regional, state, and federal governing bodies in Australia, as in the US and UK (see Sampson 2004). In 2006, the Australia Council for the Arts (ACA) called for public comment on the 'current and potential role of the arts and health' to assist it in developing a national strategy that aims to 'build awareness of the benefits of the arts on health', 'promote research', and 'identify opportunities for partnerships across the arts and health sectors'. In 2007, it followed up by calling for expressions of interest to develop an 'arts and health demonstration project', which would bring together theory and practice in the field of arts and health (Australia Council for the Arts 2007). With rapidly escalating healthcare budgets, it probably makes good sense to support efficient, low-cost interventions.

Writing therapy has been 'variously addressed in the literature as a discipline, a therapeutic entity (eg, practice model), set of adjunctive techniques, theory and philosophy' (Mazza 2003: 2). At this stage, writing therapy as profession or discipline appears more closely aligned with the 'helping professions' than with writing professions, despite its evident literary antecedents.

Bertha Pappenheim, or 'Anna O' - the 'first patient of psychoanalysis' - was also a 'storyteller' according to Jeffrey Berman. Pappenheim invented the term 'talking cure' to describe her therapy with Joseph Breuer who later included her case in Studies on hysteria (1988/1895), which he co-authored with Freud. Although it is now clear that Breuer's treatment of Pappenheim was compromised and not especially successful, Pappenheim later recovered from her wide array of ailments and became a wellknown author and feminist. Berman considers that the 'motive that prompted her to enter therapy, escape from imaginative terrors, was also the impulse behind her fiction. It was as if the creative and therapeutic processes were inseparably joined' (1985: 2). 
The psychotherapeutic method developed by Freud and Breuer has roots in confession, which Eugenia Georges describes as a historically and culturally determined form of 'symbolic healing' based on the 'ritual use of words and symbols' (1995: 12). Georges notes that psychoanalysis was not invested in confession's ethical and religious dimensions but consolidated its medical purpose:

Confession in the West has a long history as a culturally authorized 'idiom of distress' that is associated with some benefits to body and soul. The authority of confession as a form of healing is strengthened by its long history of therapeutic association in the West and the more recent imprimatur of health psychology and psychosomatic medicine. (1995: 15)

Freud's techniques of interpretation and construction, his interest in memory, catharsis, story, dream, and symbol - or, broadly, in narratology and poetics are grounded in literature and have, in turn, profoundly influenced literary production, cultural theory, philosophy, and criticism as well as ways of treating mental illness (Brophy 1998; Brooks 1994; Felman 1995). Wilma Bucci observes that many of Freud's methods and concepts, especially the 'fundamental notion of unconscious mental processes, the technique of free association in the context of the therapeutic relationship, and the curative effects of remembering and talking', continue to 'exert their influence today, not only in psychoanalysis proper, but in most treatments in the United States and around the world' (1995: 94). Jeremy Holmes notes the importance of 'metaphor, story-telling, the search for event-scripts, and the role of "narrative competence" as a mark of psychological health'. Psychotherapy, he asserts, is 'a quintessentially narrative discipline' (2000: 92).

Lepore and Smyth attribute the recent rise of interest in writing therapy to a number of factors, including the success of a 'writing intervention' pioneered in the 1980s as part of empirical research by James W Pennebaker, writing therapy's cost-effectiveness, and the ease with which writing overcomes some of the usual barriers to self-disclosure, such as lack of access to services or personal inhibition (2002: 6).

Pennebaker's writing intervention describes controlled 'laboratory' trials in which healthy people usually write for between 15 and 30 minutes per day for three to five consecutive days. Experimental participants write on their deepest thoughts or emotions relating to a negative or traumatic experience; controls on trivial or routine matters. Participants are told there will be no feedback; they are not to worry about spelling, grammar, or sentence structure; and confidentiality is assured (Pennebaker and Beall 1986; Pennebaker 1990/1997, 1993, 2002).

Pennebaker and Cindy Chung (2007) note that the first writing study was published in 1986; by 1996, approximately 20 studies had been published, and by 2006 well over 150 had been published in English language journals, many of which support early findings that writing about stressful experiences can confer benefits across a range of measures, including reduced health centre visits and self-reported illness, improved immune function, and better work and study performance. While the emphasis has been largely on physical health and biological outcomes, increasingly researchers have considered writing's effects on 'attitude change, stereotyping, creativity, working memory, motivation, life satisfaction, school performance, and a variety of health-related behaviors' (Pennebaker and Chung 2007: 7). Many studies have used healthy participants, particularly American college students, but increasingly the writing intervention is being trialled with those who have experienced specific traumas 
such as rape or bereavement relating to suicide, or who live with illnesses such as cancer, asthma, rheumatoid arthritis, fibromyalgia, chronic pelvic pain, posttraumatic stress disorder, Epstein Barr virus, HIV infection, or high risk drug dependency. (See for example, Low et al 2006; Smyth et al 1999; Harris et al 2005; Broderick et al 2005; Gillis et al 2006; Norman et al 2004; Bernard et al 2006; Esterling et al 1994; Petrie et al 2004; Baikie et al 2006.)

In 1998, Smyth published 'Written emotional expression: effect sizes, outcome types, and moderating variables' in the Journal of Counselling and Clinical Psychology to assess the randomised, controlled studies that had so far been carried out by Pennebaker and other researchers. Smyth's 'meta-analytic review' of the literature evaluated the 'brief writing task' originated by Pennebaker and also whether participant characteristics, type of outcome (self-report or objective data), or 'dose' (amount of writing) affected the findings. Thirteen studies qualified for his review: eight involved Pennebaker (Smyth 1998: 175).

Smyth found that overall there was a $23 \%$ improvement in the experimental group over the control group (illness decreased from $61 \%$ in the control group to $38 \%$ in the experimental group). This suggests that writing therapy is as effective, or more so, than other psychological, behavioural, or educational treatments (Smyth 1998: 179). Smyth concluded that the 'strong effect on physiological measures provides support for the biological impact of writing' (1998: 180).

Two years later in the journal Literature and Medicine, Pennebaker noted that in the decade to 2000 'several dozen studies from multiple laboratories around the world' had confirmed and extended his findings, with the benefits 'applying across various social classes and 'racial/ethnic groups'. The effects of writing were 'not related to the presumed audience' and were no different, for example, when people wrote on a 'child's magic pad where their writing was erased as soon as they lifted the plastic sheet on the writing tablet' (2000: 6). However, as Pennebaker and Chung recently acknowledge, the degree to which people write 'holding the belief that some symbolic other person may "magically" read their essays can never be easily determined' (2007: 15).

In 1990, Pennebaker published Opening up: the healing power of expressing emotions for a general readership and lay publications also began to publish articles in the early nineties 'lauding the benefits of emotional writing' (Smyth 1998: 174). Positive findings from controlled studies have helped to create clinical and public confidence in an accessible form of therapy that might otherwise have been deemed idealistic or 'alternative' and remained marginalised. Confidence in the method is illustrated by the employment of writers to conduct healing workshops in the aftermath of tragic events such as the Columbine shootings or the 11 September 2001 terrorist attacks.

However, as noted by Lepore and Smyth, 'not all studies show positive effects of writing, and not all persons who write show benefit ... Some scholars have, in fact, been forthright in their scepticism' (2002: 7). For example, Trisha Greenhalgh (1999) queried a study that found writing about stressful events led to symptom reduction in patients with asthma or rheumatoid arthritis (see Smyth et al 1999). She considers it 'frankly implausible' that writing for 60 minutes could have a clinically relevant impact on two different chronic diseases four months later, but she also rejects the study on the grounds of 'validity and generalisability'. The potential biases in the study, she claims, are 'not difficult to spot'. Her concern relates partly to popularisation of the concept of writing therapy, which could influence participant and assessor expectations and thereby skew the results of randomised trials. 
In addition, a systematic review of emotional disclosure studies found opinion that the writing intervention is beneficial 'needs to be reassessed in light of the totality of evidence available' (Meads and Nouwen 2005). According to Pennebaker and Chung, the reviewers, from a medical background, were 'befuddled by the fact that most of the experimental studies of expressive writing were more theory-oriented and not aimed at clinical application'. They counter that since the review a new wave of random controlled trials is being conducted 'with a diverse group of patient populations' (2007: 8).

On balance, and in light of a subsequent analysis of 146 randomised studies that finds expressive writing is effective (Frattaroli 2006), we can reasonably assume that expressive writing can be therapeutic for some people in some situations.[5]

But why is writing remedial? Laura King asserts: 'Two strong conclusions can be made with regard to the benefits of expressive writing. First, expressive writing has health benefits. Second, no one really knows why' (2002: 119). In her review of the literature in Writing cures, Jeannie Wright concludes that 'whether or not we can explain the mechanism that produces the benefit', the evidence is clear that 'writing about a major transition, such as the experience of moving into higher education, results in health and other benefits, including improved academic performance' (2004: 12).

Expressive writing 'sets off a cascade of effects', according to Pennebaker and Chung, and they warn against simplification:

There is no single reason that explains the effectiveness of writing ... Over the last two decades, a daunting number of explanations have been put forward and many have been found to be partially correct. Ultimately, there is no such thing as a single cause for a complex phenomenon. (2007: 21-22)

Initially, disclosure was a key candidate and it is still considered a remedial factor. In Emotion, disclosure and health, Pennebaker asserts that 'links between disclosure and health have now been firmly established' (1995: xiii). Smyth's 1998 analysis finds that 'emotional expression may be necessary', but it is 'not sufficient to produce positive change'. However, emotional expression facilitates 'cognitive processing' of traumatic memory, and such processing appears responsible for affective and physiological change. Smyth's review of several studies on trauma and memory suggested to him that traumatic memories are 'emotional and perceptional', 'encoded differently', and 'not integrated into a personal narrative'. Memory that is stored as 'sensory perceptions, obsessional ruminations, or behavioural reenactments' may be persistently intrusive and distressing: 'Writing about the traumatic event may force the transduction of the memories from sensory-affective components into an organized, linguistic format' (Smyth 1998: 180).

Studies using specially designed computer software to analyse writing produced in trials and other situations have found particular stylistic elements tend to correlate with improved health outcomes: for example, high levels of positive emotion words, moderate levels of negative emotion words, increasing use of insight and causal words such as 'understand', 'realise' and 'because' from the first writing day to the last, and ability to change perspectives from one writing session to another (Lowe 2006; Pennebaker 2002; Pennebaker and Chung 2007).

Cognitive processing is indicated by the ability to construct a competent narrative and consequently narrative has achieved greater causal significance 
than disclosure in recent understandings of writing therapy. According to Pennebaker and Seagal in the Journal of Clinical Psychology:

Once an experience has structure and meaning, it would follow that the emotional effects of that experience are more manageable. Constructing stories facilitates a sense of resolution, which results in less rumination and eventually allows disturbing experiences to subside gradually from conscious thought. (1999: 1243)

Researchers have found that dance or bodily movement therapy in expressing trauma is far less effective than writing about it. 'The mere expression of a trauma is not sufficient to bring about long-term physiological changes. Health gains appear to require translating experiences into language' (1247-48). In 'Telling Stories: The Health Benefits of Narrative', Pennebaker insists that 'catharsis or the venting of emotions' without 'cognitive processing' has little therapeutic value and people need to 'build a coherent narrative that explains some past experience in order to benefit from writing' (2000: 10-11).

In 2001, Jeannie Wright and Man Cheung Chung published 'Mastery or mystery? Therapeutic writing: a review of the literature' in which they claim (after McLeod 1997) that the 'history of using client writing in a therapeutic setting ... is long' but also that writing therapy has been 'restimulated by the development of narrative approaches'. Their pretext for the review is 'recent developments in online support and counselling', which suggest that users of chat rooms and email help services have 'discovered the power of writing as a self-help vehicle' (Wright and Chung 2001: 278). Their overview posits that research endorsing writing as therapy exists on a continuum between 'mastery and mystery'. Those with a mystery or 'humanities approach', generally with a literary arts or creative writing background, tend to draw on their experiences as writers and facilitators of creative writing groups and 'the therapeutic benefits of writing are explored with an enthusiasm verging on the evangelical' (2001: 278). On the other hand, those who 'follow a more scientific paradigm, from disciplines including immunology, health and social psychology, seek to "master" the phenomenon by measuring, explaining, predicting and analysing the results of randomised, controlled trials' (2001: 278). These studies, Wright and Chung believe, 'clearly demonstrate the benefits of "writing therapy" for both physical and mental health' though 'definitive comparisons are difficult to draw because of variables in follow-up periods, diagnosis of the degree of the initial traumatic experience, or the amount of words actually written' (2001: 285). They also observe that 'writing' in the humanities paradigm tends to mean 'creative writing', whereas quantitative research focuses on expressive accounts; however, the 'narrative approach' emerges as an underlying link between science and humanities approaches (2001: 285).

Mazza observes that the 'emergence of constructivist and narrative approaches' to clinical practice contributed 'to a stable base' for the establishment of writing therapy (Mazza 1999: 13). Influenced by aspects of postmodern literary theory and poststructuralism, in particular by Derrida and Foucault, Michael White and David Epston published Narrative means to therapeutic ends in 1990, which considers how people reiterate particular and often limited stories about themselves, whereas different stories might lead to other, more productive understandings and behaviours. Narrative therapy seeks to enable clients to contextualise and deconstruct the self-stories they live by, externalise their problems, and then to 're-author' their lives and relationships. Authoring tends to be used metaphorically, because this form of therapy does not rely on writing, though sometimes expressive forms, such as letters to significant others, are deployed.[6] 
It appears from our survey of the literature thus far that 'mystery' or humanities contributors to writing therapy discourse, and also clinicians advocating creative and life writing by patients (and in some cases by medical students, doctors, and therapists), tend to cite legitimating scientific studies, but that those using the 'mastery' approach seldom find cause to cite the works of humanities scholars and creative writers, which rely more on personal experience, observation, case studies, and self-reports by students, clients, therapists, or community writers. Although Wright suggests there is a 'powerful sense of commonality' (2004: 13) between the approaches, it seems that the 'humanities body of research' must be 'strengthened' - or grounded - by corroborative evidence from the other end of the spectrum.

The two approaches to writing therapy - scientific and humanities - recall psychologist Jerome Bruner's differentiation between paradigmatic knowing, which aims at replicable, verifiable evidence, description, and explanation and 'narrative knowing', which searches for meaning, appeals to verisimilitude, to specific experience, and arises out stories people construct about themselves and others (Bruner 1986: 11-13). Interestingly, it turns out that scientific approaches have helped to confirm the importance of narrative knowing to health and wellbeing. Indeed, Pennebaker and Seagal conclude that 'a constructed story ... is a type of knowledge that helps to organise the emotional effects of an experience as well as the experience itself' (1999: 1249).

It is not surprising, then, that interest in writing as therapy has occurred alongside escalating interest in life-writing as a mediated, reflexive, creative process of narrative and identity construction. Life-writing is commonly regarded as an effective intervention in the project of understanding - and perhaps (re)making - the self. Dan McAdams observes that in a contemporary context 'the self is a reflexive project that a person is expected to "work on", to develop, improve ... and strive to perfect'. The construction of the self requires individuals to draw upon available symbols, myths, genres, discourses, and narratives:

[people] feel a strong urge to find some coherence in the self, to fashion a self that is more or less unified and purposeful and unified within the discordant cultural parameters that situate their lives...people pick and choose and plagiarise selectively from the many stories and images they find in culture in order to formulate a narrative identity' (2003: 202).

Memory is a key concern of life-writing scholars as it is for psychotherapists:

Memory ... which often has to do not merely with recounting the past but with making sense of it - from 'above', as it were is an interpretative act the end of which is an enlarged understanding of the self. (Freeman 1993: 29)

Paul Eakin stresses the link between narrative and identity in both internal lifestory and autobiography: 'narrative is not merely a literary form but a mode of phenomenological and cognitive self-experience, while self - the self of autobiographical discourse - does not necessarily precede its constitution in narrative' (Eakin 1999: 100).

The term 'dysnarrativia' has been coined to describe the documented inability to construct self-narrative by those suffering amnesia, autism, severe child abuse or brain damage. The lack of ability to achieve narrative construction seems to be correlated with identity disorders (Eakin 1985: 124). 
As mentioned, the reasons why life-writing has the therapeutic benefits of, for example, 'striking physical health and behaviour change' as claimed in the Clinical Psychology Review (Esterling et al 1999: 84) are still being theorised. Pennebaker and others have suggested that the confrontation and processing of problematic life events through narrative helps the subject assimilate such problems; this view is supported by various 'field' researchers, including Mari Alschuler. Alschuler worked with a group in East Harlem, all of whom had challenges including mental illness, drug dependency and homelessness. She asked them to identify a 'specific incident, person or time period' (1997: 116) to write about, while others researched family history. Alschuler gave them basic narrative craft tools including point of view, dialogue and narrative flow and the group was encouraged to make positive suggestions about each other's work. She claims that this writing developed the participants' 'sense of self and ego strengths ... [and] connected them to important others in their lives' (1997: 113).

As many writing teachers may have observed, however, writing about traumatic events can cause students to be anxious, sad, and distressed. Formal studies corroborate such effects, even where people experience benefits in the long term. This may discourage some individuals from attempting writing therapy on their own or even as part of supervised treatments (Pizarro 2004). It may also warn off writing teachers or community writing facilitators who are not trained and equipped to deal with mental health crises. The risks need to be discussed with participants and support measures put in place before life writing is undertaken, but especially when it involves participants who have an illness such as depression or post-traumatic stress disorder. These situations would require oversight by clinicians, perhaps working in tandem with a professional writer.

Notably, researchers have found that when previously traumatised students wrote about someone else's trauma as if they themselves had lived through it, the health outcomes were comparable to those achieved by people writing about their own experiences (Greenberg et al 1996). This concurs with something many creative writers may have intuited: 'the writing topic need not be rooted in the individual's own life for benefits to occur' (King 2002: 123) and other types of imaginative writing may be as beneficial to health and wellbeing as life writing. While all writing is potentially risky, focussing on imagined trauma and experimenting with various forms and genres might be useful distancing devices for some people.

Recent studies have also shown that writing about past trauma or negative emotion is not essential to producing benefits. For example, topics such as coping with a future stressful event or writing only about the perceived benefit of their trauma or even about one's best possible future self (King 2002) can all be beneficial for well-being and physical health, which suggests that a broadrange of writing approaches and topics can be deployed where emphasis on personal, traumatic life experience may be problematic.

In The therapeutic potential of creative writing, Gillie Bolton asserts there is 'no real distinction' between creative writing and therapeutic writing and that both would 'lose much of their power if there was'. Bolton is aware that her claim will be controversial: 'I cannot ... maintain that all creative writing has a therapeutic element or stage, even if that is what I believe, since there are writers who deny it of their own work' (1999: 13). Also, although she claims 'therapeutic writing is creative' and that creativity is one of its therapeutic benefits, she does not suggest that all therapeutic writing will be 'art'. It might, on redrafting, become art, she suggests, but 'no beginning or therapeutic writer 
will benefit from thinking their writing may be shareable with a wide audience as art' (1999: 14).

This is worth bearing in mind, though the term 'art', like 'literature', carries much historical and ideological baggage. Teachers of creative writing may nevertheless be interested in well-established connections between healing and guided life-writing. In 1989, for example, Marilyn Chandler stressed relations of catharsis, healing and narrative craft:

Designing and telling a life story is purgative, reconstructive, integrative, transformative activity. The basic requirements of narrative - pattern, structure, closure, coherence, balance - all engage a writer in creating a whole out of fragments of experience. (1989: 6)

Though we are fully aware of the theoretical complexities not addressed by such arguments (for example, the ongoing debate about the instability of the autobiographical self, the distance between the 'I' of the text and the 'I' of the writer at any moment, or the distance between the act of writing and the lived experience), it seems to us that our awareness of the construction of the self through language lends impetus to the life writing as therapy case, rather than undermining it. If in life writing the agent is under the 'illusion of drawing the contingencies of existence into a configuration that suggests stability over time' (Crowley 2003: 9) then that is an inescapable illusion and a workable way of being in the world that confers benefits.

Psychiatrist Judith Herman (1992) and creative writing academic Vicki Linder (2004) argue that life-narratives are more therapeutically effective if guided to be written according to some fundamental aesthetic conventions including structure, avoidance of cliché, observation of the 'demonstrate don't state' dictum, and overall coherence.[7] Linder has found that her undergraduates, no matter how genuine their life traumas, without craft guidance tend to write 'naively constructed stories, unmediated by advanced literary skills' (2004: 7). Similarly, Herman finds a patient's initial accounts of a trauma or problem prone to be 'repetitive, emotionless, and incomplete, its images buried, or not verbalised' (cited Linder 2004: 8).

Hence there is a role for creative practitioners as facilitators in potential therapeutic projects. As Linder notes, Herman's account of the healing narrative that has to be thoughtfully constructed 'resembles what a creative writing teacher would identify as effective writing' (2004: 8), that is, in Herman's words, 'an organised, detailed, verbal account, oriented in time and historical context' which adds a 'larger dimension to the victim's experience', providing the potential for better situating oneself within a social context in which new relationships can be formed (1992: 176).

A key point of therapeutic writing - whether it takes the form of autobiography, fiction or poetry - is that its focus is the process of writing, rather than the end product. Interestingly, though, writing appears to be most beneficial to health if it moves through developmental stages typical of writing designed for a readership (Bolton and Latham 2004). Creative writing in the university workshop also tends to focus largely on process, so that facilitators might encourage free association; continuous writing without regard for grammar, punctuation or syntax; experiments with perspective, voice, and imagery; revision and drafting. Some aspects of standard workshop practice, including the importance of accessing 'unconscious' material, grammatical and syntactical freedom, clear parameters, time limits and respect for confidentiality are also replicated in controlled writing trials. Transformation in the writing over time - 
or increasing insight and narrative competency - is relevant to both literary and health assessments. However, in therapeutic contexts, the stress of demonstrating literary knowledge and originality, together with professional and editorial skill is removed.

Wilma Bucci has devised a 'multiple code account', supported by computerassisted textual analysis, to help explain the recuperative 'power of narrative' or what turns out to be, essentially, the power to make images and meaningfully connect them. In doing so, she describes a process that is 'fundamentally creative'. Verbalising converts 'subsymbolic' experience into a 'symbolic format' as part of a 'referential cycle', the stages of which are parallel to stages of creative production or invention, summarised in familiar terms by Bucci as preparation, incubation, illumination, and verification (1995: 108).

Mark Robinson draws on Bucci's model to link writing well with better health and wellbeing. In other words, despite traditional tensions, therapeutic and aesthetic intentions may not be incompatible. Robinson contends that 'some elements of "quality" are intrinsic to the therapeutic benefits of writing' (2000), and he encourages research on the topic: 'the importance of literary quality, and the re-writing process involved, as well as the value of disclosure, needs to be examined further as writing is increasingly used therapeutically' (2000).

In tertiary education, the value of writing personal essays, poetry, and fiction continues to be debated. Arguably, some writers and academics are wary of writing as therapy because it raises the spectre of spontaneous, confessional, ill-conceived, and potentially tedious and narcissistic texts - although these are precisely the kinds that do not appear to produce health benefits. As Robinson observes 'While many people have testified that creative writing can have therapeutic effects ... this is often seen as somehow ruling out the possibility of the writing's being of a high literary quality according to the dominant paradigms of "excellence" within English-speaking culture' (2000: 2).

Asserting that expressive and creative writing are therapeutic when students are directed to write about deeply personal and even painful or traumatic experiences may only fuel arguments that such writing belongs in clinics rather than universities; that is, some will consider that it is not the role of educators and educational institutions to facilitate healing.

So, is writing the self, and especially the traumatised self, as part of university coursework pedagogically useful and ethically sound? There is not space to consider the issue here, but in Therapeutic dimensions of autobiography in creative writing, Celia Hunt (2000) draws on narrative, psychoanalytic, literary, and cultural studies theory, as well as from the growing field of creative writing theory and practice, to argue for the importance of autobiographical writing as both an opening into fiction writing and a powerful therapeutic tool.

In Signifying pain and healing the self through writing, Judith Harris also presents a positive argument suggesting creative writing workshops can become healing communities, sites where students learn effective writing, empathy, and a means of recuperation. Aware that personal writing is 'often dismissed as too self-referential' (2003: 11), Harris attempts to establish the relation of the individual psyche to larger systems, social, political, domestic, sexual, racial. She draws on the work of established writers, from Charlotte Perkins Gilman to Derek Walcott, to support her case.

In Risky writing: self-disclosure and self-transformation in the classroom, Jeffrey Berman advocates personal writing in composition classes, that is, essays that examine disturbing, even traumatic details of students' lives. He regards such writing as potentially empowering and beneficial: '[s]tudents who 
engage painful subjects write from the point of view of a survivor rather than a victim; their writing is not confessional but transformational' (2001: 20). However, Carra Leah Hood (2005) rejects such a notion as both as unethical and superficial in its understanding of the relationship between writing, trauma, and recovery. To help her contest Berman's position, she draws on an article by Susan Swartzlander, Diana Pace, and Virginia Lee Stamler, 'Requiring students to write about their personal lives' (1993), which rejects such practice as 'shockingly unprofessional' and points to concerns about 'grading, retraumatization, and gender' (1993: 1), and also on Petar Ramadanovic's essay 'In the future ...: on trauma and literature' (2002), which 'argues against equating writing and healing because the equation is embedded in a perception of survivors that ... situates them at the center of the recovery effort'. Hood claims that 'students' testimony and research evidence on the effects of trauma indicate that transformational processes are more enduring than one semester and exceed the temporal and spatial parameters of the classroom' (2005: 4).

Hood also takes issue with views in Writing and healing: toward an informed practice edited by Charles Anderson and Marian MacCurdy (2000), where a strong case is made for exploration of deeply personal experience in writing education as a means to assist students in recovering and mastering painful experiences. She complains that some writing teachers assume 'even more profoundly than therapists ... that the act of writing constitutes, rather than supplements or informs, healing' (2005: 11-12).

Hood is concerned that in such discourse 'writing appears to accomplish healing magically' (2005: 12). She resists the 'intervention of magic' in the equation of writing and healing because

both writing and healing require extremely hard work, not obviously the same hard work. If writing is healing, or if healing takes place through writing, it is, or does so, because the two processes cohere. To appear other than an assertion derived from desire, Anderson and MacCurdy need to specify how the processes of writing intersect with those of healing to accomplish the transformation of one into the other. (2005: 13)

There are good reasons for academics exploring the potential of writing therapy to consider Hood's - and others' - concerns, despite research that does suggest how the processes intersect. There is a danger in too readily associating writing with healing, for writing might become valorised and overly burdened: claims for its therapeutic value may be overstated and its difficulties elided.

Furthermore, psychoanalysis has endured repeated attacks on its legitimacy and efficacy, and it is debateable whether it has fully secured them even now. Literature is guaranteed neither position nor esteem; its relevance and worth must be continually reiterated in educational and public contexts. Perhaps unsurprisingly, creative writing as a 'sub-category' has not always been readily accepted within English departments, and its role in universities continues to invite questions and disquiet among some scholars and the public, as we are reminded by Nigel Krauth and Tess Brady in their introduction to Creative writing: theory and practice (2006). Creative writing theory and research, as they point out, is vitally eclectic: it draws on a broad range of other disciplines and bodies of knowledge which bring to it 'a richness, a complexity' (2006: 16). However, we would argue that this new academic discipline - though certainly gaining ground - is evolving and still striving to gain scholarly 'authority' as it does so. 
The introduction of writing therapy to university writing courses risks compromising the status of a discipline that already has challenges aplenty. Its roots in literature and psychoanalysis, that is, in two disciplines whose value is constantly debated, and which initially competed with each other for primacy (Brophy 1998), together with its dependence on creative writing, also a contested field, suggests those invested in its success would need to work hard to ensure its pedagogical, aesthetic and therapeutic potential can be realised.

In our view, the risk is worth taking: creative writing and writing therapy share common ground. They would inevitably accommodate and contest each other in ways that could enhance the theory and practice of teaching and writing, and engender new research in both fields. Writing therapy draws upon multiple theories of language, memory, pain, subjectivity, agency, identity, creativity, and the unconscious. It is a site at which the concerns of established and emerging disciplines and interest groups coalesce; for example, literary criticism, narrative therapy, narrative medicine, trauma studies, human rights, life writing, and testimony studies. In studies that address 'social suffering', as Maura Spiegel and Rita Charon put it, 'none of our disciplinary resources alone can be adequate to identify and respond to the sources or scale of misery in our times, so we must continue to break down the boundaries between disciplines' (2005: vii).

Writing as therapy is a field of practice and theory still under construction, and there will need to be negotiation and collaboration with longer-standing disciplines (for example, those psychologists involved in art therapy, and more recently, narrative therapy, who are experienced in designing research instruments which can deal rigorously with the issue of measuring health or wellbeing outcomes for individuals). But increasingly there is convincing evidence of its physical and mental health benefits. It presents a fascinating challenge for the discipline of creative writing. We believe there is potential for university writer-teachers to investigate writing therapy in academic, health science and community settings. Publications arising from theoretical and practice-led research would usefully contribute to debates on the benefits of various forms of writing to individual and community health and wellbeing, which might in turn encourage appropriate levels of government and institutional recognition and support for what is a relatively low-cost intervention.

\section{Endnotes}

1. A unit entitled Writing Therapy was introduced in 2008 by Ffion Murphy as part of ECU's writing major and double major in psychology and writing. Students explore the concept and practice of writing therapy and its relation to psychoanalysis, medicine, literature and history, asking what claims are made for it and what assumptions underpin it. In keeping with tenets of 'practice-led' research, students also engage in and evaluate various kinds of writing therapy, including personal essays, autobiography, fiction, poetry, letter, and journal therapy. The related field of testimony studies will be introduced, and stories bearing witness to injustice and persecution considered for their effects on storytellers, readers, and modes of historical, political and literary discourse.

In conjunction with psychologists and art therapists from the University of Queensland's School of Medicine, in particular Professor Robert King, and with Seiji Humphries from the Richmond Queensland Fellowship, in early 2008 Philip Neilsen designed and conducted a series of pilot study workshops with voluntary participants who have severe mental illness. The life-story workshops (for which a manual was designed by Neilsen) was conducted with a group of approximately ten people, guiding them in the principles of effective life-writing and related writing exercises, and encouraging them to write memoir, generally with an emphasis on 'recovery' as understood within mental health literature as better negotiating daily living and 
achieving a sense of agency, rather than seeking a 'cure'. Psychologists and health workers from University of Queensland/Mater Hospital are currently undertaking qualitative measurement of the success or otherwise of the workshops from the participants' perspective, to ascertain whether participants consider they have benefited from the workshops, especially in terms of an enhanced sense of well-being or agency. Early feedback is encouraging, with participants enthusiastic about the possibility of attending further workshops. In conjunction with Visual Arts therapists from La Trobe, a much more comprehensive study over three years is hoped to be embarked upon. One early (and not unexpected) finding of the pilot study is that in the case of participants with severe mental illness (such as bi-polar disorder or schizophrenia), workshop participants will vary in their ability or willingness to confront past trauma through life writing. While some are enthusiastic about writing of their illness and related past experience, others prefer to write 'recovery' narratives that stress positive life-stories of, for example, establishing a community connection, or overcoming a difficulty. return to text

2. Arthur Frank is interested in the ethical dimensions of wounded storytelling, rather than the kinds of stories some accuse of commercially and perhaps cynically exploiting both misery and confession - that is, contributions to the so-called 'misery memoir' or 'mis-lit' genre. Frank Furedi (2007), for example, describes this type of narrative as 'the pornography of emotional hurt ... These memoirs confess to so much that they take on the character of a literary striptease. They provide titillating and very graphic accounts of traumatic pain which actually turn readers into voyeurs. And, as in real porn, there is a lot of faking going on, too'. return to text

3. Readers interested in this subject might wish to review computer-assisted studies of word usage. For example, see 'Word use in the poetry of suicidal and non-suicidal poets' by Stirman and Pennebaker (2001). In 'The psychological functions of function words', Pennebaker and Chung (2007) note that across 'multiple studies' they found that 'the use of first person singular is associated with negative affective states' and that in a 2001 analysis of 'the poetry of suicidal versus non-suicidal poets, poets who eventually committed suicide used first person pronouns at higher rates than those who did not commit suicide ... Overall, suicidal poets' language use showed that they were focussed more on the self and were less socially integrated than nonsuicidal poets' (2007: $350-51)$. return to text

4. NFBPT has information on training courses and registration. It is possible to become a Registered Poetry Therapist, a Certified Poetry Therapist or a Certified Applied Poetry Facilitator. The latter category caters for those who are not state-licensed therapists. return to text

5. For a useful overview of expressive 'writing paradigm' research and models of trauma see Guastella (2004), chapter 1. return to text

6. White and Epston's narrative approach is shared by Monk et al in Narrative therapy in practice: The archaeology of hope (1997) and explained on the Dulwich Centre website, which offers a 'gateway to information about narrative therapy'. return to text

7. A trial week of community digital storytelling workshops at QUT in 2005 - Sharing Stories - in which Neilsen participated, indicated that basic guidelines were found useful by participants who had not previously attempted writing an autobiographical script, or any other form of creative writing.

See http://www.kgurbanvillage.com.au/sharing/dstories/index.shtm for the digital stories produced during the workshop. return to text

\section{Works Cited}

Adams, K 1990 Journal to the self, New York: Warner Books return to text

Adams, K 1994 Mightier than the sword, New York: Warner Books return to text

Alschuler, M 1997 'Lifestories - biography and autobiography as healing tools for adults with mental illness', Journal of poetry therapy, 11.2, 113-17 return to text

Anderson, CM and MM MacCurdy (eds) 2000 Writing and healing: towards an informed practice, Urbana, IL: NCTE return to text 
Andreasen, NC 1987 'Creativity and mental illness: prevalence rates in writers and their firstdegree relatives', American Journal of Psychiatry, 144.10, 1288-92 return to text

Australia Council for the Arts 2007 'Expressions of interest for arts and health demonstration project' http://www.australiacouncil.gov.au/news/news_items/expressions_of_interest_for_arts_ and_health_demonstration_project return to text

Australian \& New Zealand Art Therapy Association (ANZATA) 2006

http://www.anzata.org/mambo/index.php?option=com_frontpage\&Itemid=1\&PHPSESSID $=50 \mathrm{a} 8 \mathrm{e} 24 \mathrm{c} 3 \mathrm{~d} 760$ ceef54afafff70481b7 return to text

Australian and New Zealand Psychodrama Association Incorporated (ANZPA) 1999 http://www.anzpa.org/\#aboutanzpa return to text

Australian Music Therapy Association (AMTA) n.d. http://www.austmta.org.au/ return to text

Baikie, KA, K Wilhelm, B Johnson, M Boskovic, L Wedgwood, A Finch and G Huon 2006 'Expressive writing for high-risk drug dependent patients in a primary care clinic: a pilot study', Harm reduction journal, 19.3, 34 return to text

Baker, C 1986 Yacker: Australian writers talk about their work, Sydney: Picador return to text

Berman, J 1985 The talking cure: literary representations of psychoanalysis, New York: New York University Press return to text

Berman, J 2001 Risky writing: self-disclosure and self-transformation in the classroom, Amherst: University of Massachusetts Press return to text

Bernard, M, C Jackson and C Jones 2006 'Written emotional disclosure following first-episode psychosis: effects of symptoms of post-traumatic stress disorder', British journal of clinical psychology, 45 pt 3, 403-15 return to text

Blanton, S 1960 The healing power of poetry therapy, New York: Crowell return to text

Bolton, G 1999 The therapeutic potential of creative writing: writing myself, London: Jessica Kingsley return to text

Bolton, G, V Field and K Thompson (eds) 2006 Writing works: a resource handbook for therapeutic writing workshops and activities, London: Jessica Kingsley return to text

Bolton, G and Latham, J 2004 '"Every poem breaks a silence that had to be overcome": the therapeutic role of poetry writing' in G Bolton, S Howlett, C Lago and J Wright (eds), Writing cures: an introductory handbook of writing in counselling and therapy, New York: BrunnerRoutledge, 106-22 return to text

Bolton, G and JK Wright 2004 'Conclusions and looking forward' in G Bolton, S Howlett, C Lago and J Wright (eds), Writing cures, Hove and New York: Brunner-Routledge, 228-31 return to text

Broderick, JE, DU Junghaenel and JE Schwartz 2005 'Written emotional expression produces health benefits in fibromyalgia patients', Psychosomatic medicine, 67.2, 326-34 return to text

Brophy, K 1998 Creativity: psychoanalysis, surrealism and creative writing, Melbourne: Melbourne University Press return to text

Brooks, P 1994 Psychoanalysis and storytelling, Oxford: Blackwell return to text

Bruner, J 1986 Actual minds, possible worlds, Cambridge, MA: Harvard University Press return to text

Bucci, W 1995 'The power of the narrative: a multiple code account' in JW Pennebaker (ed), Emotion, disclosure and health, Washington, DC: American Psychological Association, 93-123 return to text

Chandler, MR 1989 'A healing art: therapeutic dimensions of autobiography', $a / b$ :

Auto/Biography Studies 5.1, 4-14 return to text 
Crowley, P 2003 'Paul Ricoeur: the concept of narrative identity, the trace of autobiography', Paragraph: a journal of modern critical theory, 26.3 return to text

DeSalvo, L 1999 Writing as a way of healing: how telling our stories transforms our lives, London: The Women's Press return to text

Dulwich Centre Website: A gateway to narrative therapy and community work n.d. http://www.dulwichcentre.com.au/index.htm (accessed 26 March 2008) return to text

Eakin, P 1985 Fictions in autobiography: studies of the art of self-invention, Princeton: Princeton University Press return to text

Eakin, P 1999 How our lives become stories: making selves, Ithaca: Cornell University Press return to text

Esterling, BA, MH Antoni, MA Fletcher, S Margulies and N Schneiderman 1994 'Emotional disclosure through writing or speaking modulates latent Epstein-Barr virus reactivation', Journal of consulting and clinical psychology, 62.1, 130-40 return to text

Esterling, BA, L L'Abate, EJ Murray and JW Pennebaker 1999 'Empirical foundations for writing in prevention and psychotherapy: mental and physical health outcomes', Clinical Psychology Review, 19.1, 79-96 return to text

Felman, Shoshana (ed) 1995, Literature and psychoanalysis: a question of reading, otherwise, Baltimore: Johns Hopkins University Press return to text

Fox, J 1997 Poetic medicine: the healing art of poem-making, New York: Tarcher-Putnam return to text

Frank, A W 1995 The wounded storyteller, London: University of Chicago Press return to text

Frattaroli, J 2006 'Experimental disclosure and its moderators: a meta-analysis', Psychology bulletin, 132.6, 823-65 return to text

Freeman, M 1993 Rewriting the self: history, memory, narrative, Routledge: London return to text

Freud, S 1953-75 'Creative writers and daydreaming' in The standard edition of the complete psychological works of Sigmund Freud, 143-53, London: Hogarth Press return to text

Freud, S and J Breuer 1988 [1895] Studies on hysteria, 3, London: Penguin return to text

Furedi, F 2007 'An emotional striptease', The spiked review of books, 1, May, http://www.spikedonline.com/index.php?/site/reviewofbooks_article/3353 return to text

Furman, R 2006 'Poetry as research: advancing scholarship and the development of poetry therapy as a profession', Journal of poetry therapy, 19.3, 133-45 return to text

Georges, E 1995 'A cultural and historical perspective on confession' in JW Pennebaker (ed), Emotion, disclosure, and health, Washington, DC: American Psychological Association, 11-22 return to text

Gillis, ME, MA Lumley, A Mosley-Williams, JC Leisen and T Roehrs 2006 'The health effects of at-home written emotional disclosure in fibromyalgia: a randomized trial', Annals of behavioral medicine, 32.2, 135-46 return to text

Greenberg, MA, CB Wortman and AA Stone 1996 'Health and psychological effects of emotional disclosure: a test of the inhibition-confrontation approach', Journal of personality and social psychology, 71.3, 588-602 return to text

Greenhalgh, T 1999 'Writing as therapy: effects on immune mediated illness need substantiation in independent studies', British medical journal, 319, 270-71 return to text

Greifer, E 1963 Principles of poetry therapy, New York: Poetry Therapy Center return to text 
Guastella, A 2004 Trauma writing tasks: An examination of the process of change indicated by cognitive-behavioural models of trauma, Australian Digital Theses Program, Griffith University http://www4.gu.edu.au:8080/adt-root/public/adt-QGU20040526.130108/index.html (accessed 27 March 2008) return to text

Harris, AH, CE Thoresen, K Humphreys and J Faul 2005 'Does writing affect asthma? A randomized trial', Psychosomatic medicine, 67.1, 130-36 return to text

Harris, J 2003 Signifying pain: constructing and healing the self through writing, Albany, NY: Suny return to text

Harrower, M 1972 The therapy of poetry, Springfield, Ill: Charles C Thomas return to text

Herman, J 1992 Trauma and recovery: the aftermath of violence - from domestic abuse to political terror, New York: Basic Books return to text

Holmes, J 2000 'Narrative in psychiatry and psychotherapy: the evidence?' Journal of medical ethics, 26, 92-96 return to text

Hood, CL 2005 'Lying in writing or the vicissitudes of testimony', Composition forum, 14.2, 1-15, http://www.fau.edu/compositionforum/14.2/hood-lying-writing.php (accessed 27 March 2008) return to text

Hunt, C 2000 Therapeutic dimensions of autobiography in creative writing, London: Jessica Kingsley return to text

Hunt, C and FE Sampson (eds) 1998 The self on the page: theory and practice of creative writing in personal development, London: Jessica Kingsley return to text

Hynes, AM and M Hynes-Berry 1994 [1986] Biblio/poetry therapy - The interactive process: A handbook, St Cloud, Minnesota: North Star Press return to text

Hynes, AM and M Hynes-Berry 1992 Biblio/poetry therapy: a resource bibliography, St Joseph, Minnesota: Bibliotherapy Round Table return to text

King, LA 2002 'Gain without pain? Expressive writing and self-regulation' in SJ Lepore and JM Smyth (eds), The writing cure: how expressive writing promotes health and emotional well-being, Washington, DC: American Psychological Association, 119-34 return to text

Krauth, N and T Brady 2006 Creative writing: theory beyond practice, Teneriffe, Qld: Post Pressed return to text

Lapidus 2006 http://www.lapidus.org.uk/index.php (accessed 24 March 2008) return to text

Leedy, JJ (ed) 1969 Poetry therapy: the use of poetry in the treatment of emotional disorders, Philadelphia, PA: Lippincott return to text

Leedy JJ (ed) 1973 Poetry the healer, Philadelphia, PA: Lippincott return to text

Leedy JJ (ed) 1985 Poetry as healer: Mending the troubled mind, New York: Vanguard return to text

Lepore, SJ and JM Smyth (eds) 2002 The writing cure: how expressive writing promotes health and emotional well-being, Washington, DC: American Psychological Association return to text

Lerner, A (ed) 1978 Poetry in the therapeutic experience, St Louis, MO: MMB Music Inc return to text

Linder, V 2004 'The tale of two Bethanies: trauma in the creative writing classroom', New writing: the international journal for the practice and theory of creative writing, 1.1, 6-14 return to text

Low, CA, AL Stanton and S Danoff-Burg 2006 'Expressive disclosure and benefit finding among breast cancer patients: mechanisms for positive health effects', Health psychology, 25.2, 181-9 return to text 
Lowe, G 2006 'Health-related effects of creative and expressive writing', Health Education, $106.1,60-70$ return to text

Ludwig, A M 1994 'Mental illness and creative activity in female writers', American Journal of Psychiatry, 151.11, 1650-56 return to text

Mazza, N 1993 'Poetry therapy: towards a research agenda for the 1990s', The Arts in Psychotherapy 20, 50-59 return to text

Mazza, N 1999 Poetry therapy: interface of the arts and psychology, Boca Raton: CRC Press return to text

Mazza, N 2003 'Editor's note', Journal of poetry therapy, 16.1, 1-4 return to text

McAdams, DP 2003 'Identity and the life story' in R Fivush and C Haden (eds), Autobiographical memory and the construction of a narrative self: developmental and cultural perspectives, Mahwah, NJ: L Erlbaum return to text

McLeod, J 1997 Narrative and psychotherapy, London: Sage return to text

Meads, C and A Nouwen 2005 'Does emotional disclosure have any effects? A systematic review of the literature with meta-analyses', International journal of technology assessment in health care, 21.2, 153-64 return to text

Monk, G, J Winslade, K Crocket and D Epston (eds) 1997 Narrative therapy in practice: the archaeology of hope, San Francisco: Jossey-Bass return to text

Morrison MR 1987 Poetry as therapy, New York: Human Sciences Press return to text

Munson, P 2000 'Criminal language and poetic jailbreak: writing chronic fatigue immune dysfunction syndrome', Literature and medicine, 19.1, 19-24,

http://muse.jhu.edu/journals/literature_and_medicine/v019/19.1munson01.html (accessed 27 March 2008) return to text

National Association of Poetry Therapy (NAPT) 1999 http://www.poetrytherapy.org/ (accessed 23 March 2008) return to text

Norman, SA, MA Lumley, JA Dooley and MP Diamond 2004 'For whom does it work? Moderators of the effects of written emotional disclosure in a randomized trial among women with chronic pelvic pain', Psychosomatic medicine, 66.2, 174-83 return to text

Pennebaker, JW 1997 [1990] Opening up: the healing power of expressing emotions, New York: The Guilford Press return to text

Pennebaker, JW 1993 'Putting stress into words: health, linguistic and therapeutic implications', Behavioral research therapy, 31, 539-48 return to text

Pennebaker, JW (ed) 1995 Emotion, disclosure and health, Washington, DC: American Psychological Association return to text

Pennebaker, JW 2000 'Telling stories: the health benefits of narrative', Literature and Medicine, 19.1, 3-18 return to text

Pennebaker, JW 2002 'Writing about emotional events: from past to future' in SJ Lepore and JM Smyth (eds), The writing cure: how expressive writing promotes health and emotional well-being, Washington, DC: American Psychological Association, 281-91 return to text

Pennebaker, JW 2004 Writing to heal: a guided journal for recovering from trauma and emotional upheaval, Oakland, CA: New Harbinger Publications return to text

Pennebaker, JW and S Beall 1986 'Confronting a traumatic event: toward an understanding of inhibition and disease', Journal of Abnormal Psychology, 95, 274-81 return to text

Pennebaker, JW and CK Chung 2007 'Expressive writing, emotional upheaval and health' in H Friedman and R Silver (eds), Handbook of health psychology, 263-84, New York: Oxford 
University Press

http://homepage.psy.utexas.edu/homepage/faculty/pennebaker/reprints/Pennebaker \&Chung_FriedmanChapter.pdf, 1-56 (accessed 27 March 2008) return to text

Pennebaker, JW and JD Seagal 1999 'Forming a story: the health benefits of narrative', Journal of Clinical Psychology, 55.10, 1243-54 return to text

Petrie, KJ, I Fontanilla, MG Thomas and RJ Booth 2004 'Effect of written emotional expression on immune function in patients with human immunodeficiency virus infection: a randomized trial', Psychosomatic medicine, 66.2, 272-5 return to text

Philips, D, L Linington and D Penman 1999 Writing well: creative writing and mental health, London: Jessica Kingsley return to text

Pizarro, J 2004 'The efficacy of art and writing therapy: increasing positive mental health outcomes and participant retention after exposure to traumatic experience', Art therapy: journal of the American Art Therapy Association, 21.1, 5-12 return to text

Post, F 1994 'Creativity and psychopathology: a study of 291 world famous men', British journal of psychiatry, 165, 22-34 return to text

Post, F 1996 'Verbal creativity, depression and alcoholism: an investigation of one hundred American and British writers', British Journal of Psychiatry, 168.54, 545-55 return to text

Pritchard, J and E Sainsbury (eds) 2004 Can you read me? Creative writing with child and adult victims of abuse, London: Jessica Kingsley return to text

Progoff, I 1975 At a journal workshop: the basic text and guide for using the intensive journal process, New York: Dialogue House Library return to text

Ramadanovic, P 2002 'In the future ...: on trauma and literature' in L Belau and P Ramadanovic (eds), Topologies of trauma: essays on the limits of knowledge and memory, NY: Other Press return to text

Robinson, M 2000 'Writing well: health and the power to make images', Journal of medical ethics, 26 79-84, http://mh.bmj.com/cgi/content/full/26/2/79 (accessed 27 March 2008) return to text

Rubin, R J 1978a Bibliotherapy sourcebook, Phoenix, AZ: Oryx Press return to text

Rubin, R J 1978b Using Bibliotherapy: A guide to theory and practice, Phoenix, AZ: Oryx Press return to text

Sampson, F 2004 Creative writing in health and social care, London: Jessica Kingsley return to text

Schauffler, RH 1925 The poetry cure: A pocket medicine chest of verse, New York: Dodd, Mead \& Co return to text

Schechter, RL 1983 Poetry therapy: a therapeutic tool and healing force, Connecticut: Chantry Press return to text

Schneider, M 2003 Writing my way through cancer, London: Jessica Kingsley return to text

Smyth, JM 1998 'Written emotional expression: effect size, outcome types, and moderating variables', Journal of consulting and clinical psychology, 66.1, 174-84 return to text

Smyth, JM, AA Stone, A Hurewitz and A Kaell 1999 'Effects of writing about stressful experiences on symptom reduction in patients with asthma or rheumatoid arthritis: a randomized trial', Journal of the American Medical Association, 281.14, 1304-09 return to text

Spiegal, M and R Charon 2005 'Editors' preface: The narrative imperative and the ethics of listening, literature and medicine', Literature and medicine, 24.2, vii-xii return to text 
Stirman, SW and JW Pennebaker 2001 'Word use in the poetry of suicidal and non-suicidal poets', Psychosomatic medicine, 63, 517-522 return to text

Stuart, M 1998 'Writing, the self and the social process' in C Hunt and F Sampson (eds), The self on the page, London: Jessica Kingsley Publishers, 142-152 return to text

Swartzlander, S, D Pace and VL Stamler 1993 'Requiring students to write about their personal lives', Chronicle of higher education, 17 February 1993.B1 return to text

Taylor, D 1999 'Writing as therapy', Mslexia, 2, http://www.mslexia.co.uk/back2.htm (accessed 28 May 2005) return to text

Webb, J 2003 'Depression and creative writing students', TEXT, 7.1,

http://www.gu.edu.au/school/art/text/april03/webb.htm (accessed 24 April 2003) return to text

White, M and D Epston 1990 Narrative means to therapeutic ends, New York: WW Norton \& Co return to text

Wright, J and MC Cheung 2001 'Mastery or mystery? Therapeutic writing: a review of the literature', British journal of guidance and counselling, 29.3, 277-91 return to text

Wright, JK 2004 'The passion of science, the precision of poetry: therapeutic writing - a review of the literature' in G Bolton, S Howlett, C Lago and JK Wright (eds), Writing cures, Hove and New York: Brunner-Routledge, 7-17 return to text

Zimmerman, S 2002 Writing to heal the soul: transforming grief and loss through writing, New York: Three Rivers Press return to text

Dr Ffion Murphy teaches in the School of Communications and Arts at Edith Cowan University and coordinates Honours and Postgraduate studies. Her latest book publication is Devotion (2006).

Professor Philip Neilsen works in Creative Writing and Literary Studies at QUT. His latest book publication is Without an Alibi (SALT: Cambridge, 2008).

\section{TEXT}

Vol 12 No 1 April 2008

http://www.textjournal.com.au

Editors: Nigel Krauth \& Jen Webb

Text@griffith.edu.au 